\title{
Competency in Nursing Students: A Systematic Review
}

\author{
Batool Nehrir ${ }^{1}$, Zohreh Vanaki ${ }^{2}$, Jamileh Mokhtari Nouri ${ }^{1}$, Seyyed Mohammad Khademolhosseini ${ }^{1}$, Abbas Ebadi ${ }^{1, *}$ \\ ${ }^{1}$ Behavioral Sciences Research Center, Nursing Faculty, Baqiyatallah University of Medical Sciences, Tehran, IR Iran \\ ${ }^{2}$ Nursing Department, Faculty of Medical Sciences, Tarbiat Modares University, Tehran, IR Iran
}

*Corresponding Author: Abbas Ebadi, PhD in Nursing Education, Associate Professor, Baqiyatallah University of Medical Sciences, 6th Floor, Nursing Faculty, Tehran, Iran. Mobile: +98-9122149019, Fax: +98-21-82483480, Email: ebadi1347@bmsu.ac.ir

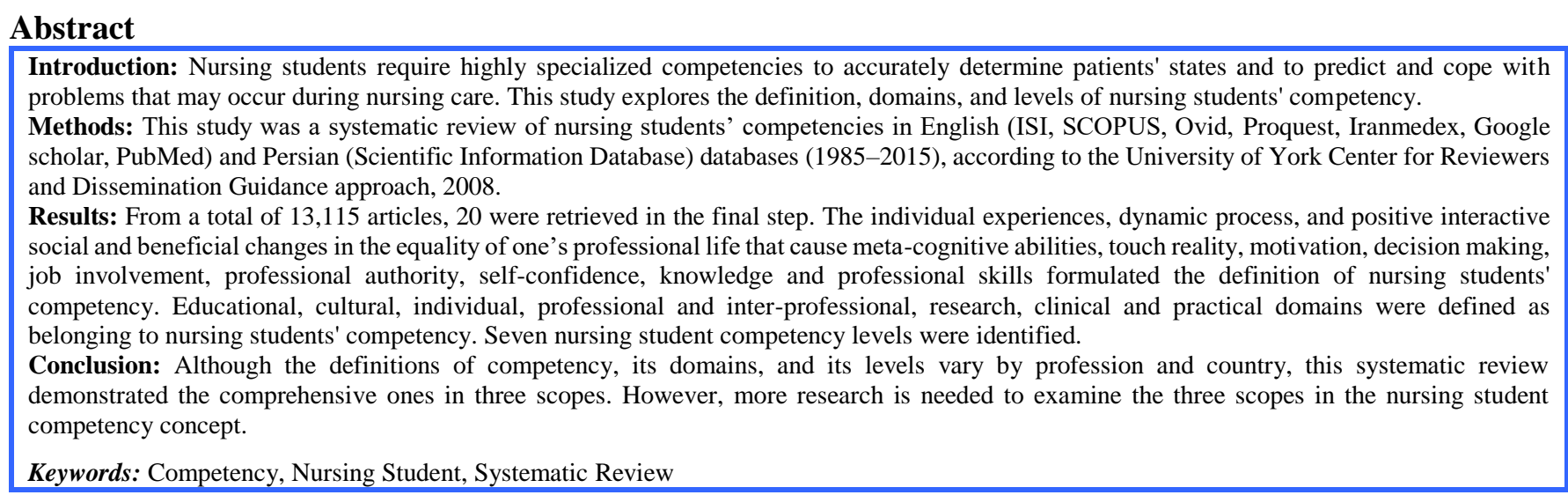

Article History: Received: 30 Oct. 2015; Accepted: 10 Jan. 2016; Online Published: 10 Apr. 2016

Cite this article as: Nehrir B, Vanaki Z, Mokhtari Nouri J, Khademolhosseini SM, Ebadi A. Competency in nursing students: a systematic review. Int J Travel Med Glob Health. 2016;4(1):3-11

\section{Introduction}

Healthcare institutions and organizations face numerous challenges, such as increasing amounts of information, the introduction of new technologies, decreased funding, and demands for accountability [1-3]; the practice of nursing requires a complex combination of various attributes [4-7], and nursing students require highly specialized competencies to accurately determine patients' states and predict and cope with the problems that may occur during nursing care $[1,8]$. The urgency of adequate nursing competencies in changing and improving care is evident. Most employers expect new nursing graduates to be prepared to perform a wide range of functions and have the skills to provide safe care [1]. Nurses at the undergraduate level should play an important role in developing the competency of new routines in quality improvement programs for patients [1]. The requirement reflected in one of the first definitions of nursing competency given by Short et al. describes a competency as a quality possessed by someone without exact specifications of what one can do in specific circumstances [5]; however, many employers are concerned that recent graduates cannot competently perform basic clinical tasks or that their education and work competencies are disconnected [1].

The assessment of clinical competency has always been a key component of clinical education for health professionals [9].

Clinical placement experiences are an integral aspect of practice development for undergraduate nursing students undertaking a Bachelor of Nursing degree to acquire competencies and abilities to learn independently, make decisions, and express ethical commitments [8, 10, 11]. Development of nursing practice requires the synchronicity of both knowledge application and clinical skills, and students must demonstrate the ability to integrate these professional requirements of the qualified nurse for which they are being prepared [4]. Otherwise, the situation results in disappointed employers, frustrated new graduates, and dissatisfied patients $[12,13]$.

According to many authors, the most effective way to ensure students acquire competencies is to integrate the teaching of those skills into course curricula in a holistic approach to teach disciplinary knowledge and generic skills [10].

A consensus was reached regarding strategies for assessing the competence of nursing students as they progress through their program of study based on the views of experienced clinicians and academics [14]. Furthermore, in health care settings, it is important to assess the competencies that are essential for the professional role of nursing students to prepare them for future professional duties [15].

However, extensive review of the literature showed that the definition of nursing student's competency, its dimensions, levels, and scopes were obscure. The purpose of this systematic review was to explore the definition, domains, and levels of nursing student's competency; it sought to answer the following questions:

1. What is a comprehensive definition of nursing students' competency?

2. What are the domains of nursing students' competency?

3. What are the levels of nursing students' competency?

\section{Methods}

For this systematic review of the competency of nursing students, the University of York Center for Reviewers and Dissemination Guidance approach was used as the research framework [16, 17]. This approach has seven steps as follows: 


\subsection{Research Question Formulation}

The study questions were three:

1. What is the comprehensive definition of nursing students' competency?

2. What are the domains of nursing students' competency?

3. What are the nursing students' competency levels?

\subsection{Defining Search Strategy}

An extensive review was made of the available literature in English and Persian databases (1985-2015), including ISI, SCOPUS, Ovid, Proquest, Iranmedex, Google Scholar, Pub Med, and Scientific Information Database (SID). The keywords searched included "nursing student competency," "nursing student ability," "undergraduate nurses competency," "nursing student professional," "nursing student skill," "clinical and educational nursing competency," "clinical qualification in nursing student," and different combinations of the aforesaid words. To find more related articles, the references of the searched articles were comprehensively investigated. Furthermore, the generalization of the retrieved final data, information, and knowledge was increased through a general and specific search on http://www.searchenginelist.blogfa.com. The mentioned site has several engine and super-engine search motors on different topics and scopes. In this section, oceans and oceans of data and information were retrieved. Some of the retrieved materials were repetitious and similar to previously searched documents, but some novel materials were detected and used in responding to Question 2. Keywords in the selected databases were utilized in the title, abstract, and keyword domains. It should be noted that some databases have overlap as some articles were cited in several databases. A reference manager software (Endnote version 7) was used to prevent re-entry of any retrieved articles.

\subsection{Setting the Inclusion and Exclusion Criteria}

The inclusion criteria for articles were publication from 1985 to August 2015; written in either the English or the Persian language; electronic publication with a formal peerreview process; congruency between the topic of the article and the study questions and purpose; application of different aspects of competency in nursing students; and originality of the paper. A total of 13,115 articles were found, including
7,730 articles in Pub Med, 3,590 in Google Scholar, 75 articles in Ovid, 14 articles in Proquest, 23 articles in Iranmedex, and 1,683 articles in SID. Searches were conducted by three members (AVA, AE, and BN).

\subsection{Designing Quality Investigation Checklist}

A checklist was designed based on the inclusion criteria, and all articles were assessed accordingly.

\subsection{Usage of the Checklist}

The full text of the articles was investigated according to the designed checklist described in the previous step. After the quality of the articles was checked, only 20 articles were retrieved in the review process (Table 1) [1, 4, 15, 18-34]. The validation processes were conducted by three members (AVA, AE, and BN).

\subsection{Deriving the Question's Responses}

Based on the research questions, the responses were extracted from the retrieved articles in the review process.

\subsection{Combination of Information Derived from Retrieved} Articles

Information derived from the retrieved articles regarding the study questions and purpose were combined in this step. Figure 1 demonstrates the flow diagram of the article selection.

\section{Results}

From 13,115 articles selected in the first step, only 20 articles remained in the last step. The core concepts in the nursing students' competency scope were related to the definition, domains, and levels of nursing student's competency. In the following, the responses of the questions are explained.

\subsection{First Question: Comprehensive Definition of Nursing Students' Competency}

The common usage domain of the word "competency" existed in nursing and midwifery education from 1983 until the present; however, authorities have expressed concern over the lack of knowledge and skills of graduating nursing students, saying that they are not necessarily equipped to work [24]. Defining and measuring competency in nursing students is difficult [35]. 
Nehrir et al. Competency in Nursing Students

\begin{tabular}{|c|c|c|c|c|c|c|c|}
\hline $\begin{array}{c}\text { Author \& } \\
\text { Data }\end{array}$ & Running Title & $\begin{array}{c}\text { Study } \\
\text { Design }\end{array}$ & Participants (n) & $\begin{array}{c}\text { Instrument/ } \\
\text { Tool }\end{array}$ & Main Results & Conclusion & Theme \\
\hline $\begin{array}{l}\text { Ebadi } \\
(2015)^{(1)}\end{array}$ & $\begin{array}{c}\text { Clinical } \\
\text { Competence of } \\
\text { Critical Care } \\
\text { Nursing Students }\end{array}$ & $\begin{array}{l}\text { Descriptive } \\
\text { cross- } \\
\text { sectional }\end{array}$ & $\begin{array}{l}250 \text { MSc students } \\
\text { of critical care } \\
\text { nursing }\end{array}$ & $\begin{array}{l}\text { Researcher- } \\
\text { made } \\
\text { questionnaire }\end{array}$ & $\begin{array}{l}\text { Five domains and higher areas of } \\
\text { clinical competency. }\end{array}$ & $\begin{array}{l}\text { To enhance the efficiency of } \\
\text { the course a revised } \\
\text { curriculum is recommended. }\end{array}$ & $\begin{array}{l}\text { Care management; Practical competency; Scholarship; Patient } \\
\text { centered. and Individualized management }\end{array}$ \\
\hline $\begin{array}{l}\text { Fan, et al } \\
(2015)^{(2)}\end{array}$ & $\begin{array}{l}\text { Performance } \\
\text { Evaluation of } \\
\text { Competency-based } \\
\text { Education }\end{array}$ & $\begin{array}{l}\text { Quasi- } \\
\text { experiment } \\
\quad \text { al }\end{array}$ & $\begin{array}{l}312 \text { second-year } \\
\text { undergraduate } \\
\text { nursing students }\end{array}$ & OSCE Checklist & $\begin{array}{l}\text { Higher scores in medical-surgical } \\
\text { nursing courses and practicum, } \\
\text { after adjusting for seven } \\
\text { covariates. }\end{array}$ & $\begin{array}{l}\text { Competency-based education } \\
\text { is worth implementing and } \\
\text { may close the gap between } \\
\text { education and the ever- } \\
\text { changing work environment. }\end{array}$ & Competency-based education; meta cognitive, and abilities. \\
\hline $\begin{array}{l}\text { Kim Fan, } \\
\text { et al } \\
(2015)^{(3)}\end{array}$ & $\begin{array}{l}\text { Professional Quality } \\
\text { of Life and Clinical } \\
\text { Competencies }\end{array}$ & $\begin{array}{c}\text { Cross- } \\
\text { sectional }\end{array}$ & 335 nurse students & $\begin{array}{l}\text { The Pro QOL } \\
\text { Questionnaire }\end{array}$ & $\begin{array}{l}\text { Low Pro QOL experience, can be } \\
\text { negatively impacted on the } \\
\text { clinical competence }\end{array}$ & $\begin{array}{l}\text { As professional quality of } \\
\text { life may affect clinical } \\
\text { competence, increase nurses' } \\
\text { compassion satisfaction and } \\
\text { relieve compassion fatigue } \\
\text { are needed. }\end{array}$ & Professional quality of life \\
\hline $\begin{array}{l}\text { Khomeiran, } \\
\text { et } \\
\text { al }(2006)^{(4)}\end{array}$ & $\begin{array}{l}\text { Influencing Factors } \\
\text { of Professional } \\
\text { Competence } \\
\text { Development }\end{array}$ & $\begin{array}{l}\text { Content } \\
\text { analysis }\end{array}$ & $\begin{array}{l}27 \text { registered } \\
\text { nurses }\end{array}$ & $\begin{array}{l}\text { Tape-recorded } \\
\text { semi-structured } \\
\text { interviews }\end{array}$ & $\begin{array}{l}\text { Experience, opportunities, } \\
\text { environment, personal } \\
\text { characteristics, motivation and } \\
\text { theoretical knowledge were } \\
\text { identified. }\end{array}$ & $\begin{array}{l}\text { Influencing factors of } \\
\text { professional competence } \\
\text { development extend across } \\
\text { personal and extra-personal } \\
\text { domains. }\end{array}$ & $\begin{array}{l}\text { Touching the realities, decision making, learning, opportunities, } \\
\text { precious experience, job involvement, motivated agent, and } \\
\text { theoretical knowledge. }\end{array}$ \\
\hline $\begin{array}{l}\text { Wu, et al } \\
(2014)^{(5)}\end{array}$ & $\begin{array}{l}\text { Application of } \\
\text { Nursing Core } \\
\text { Competency } \\
\text { Standard Education }\end{array}$ & $\begin{array}{l}\text { Quasi- } \\
\text { experiment } \\
\quad \text { al }\end{array}$ & $\begin{array}{l}42 \text { nursing } \\
\text { undergraduates }\end{array}$ & $\begin{array}{l}\text { Researcher- } \\
\text { made } \\
\text { questionnaire }\end{array}$ & $\begin{array}{l}\text { Significantly higher performance } \\
\text { in the health information } \\
\text { collection, physical assessment, } \\
\text { scenario simulation and } \\
\text { communication in the } \\
\text { experimental group }\end{array}$ & $\begin{array}{l}\text { Nursing core competency } \\
\text { standard education is helpful } \\
\text { for the training of nursing } \\
\text { students' core competencies }\end{array}$ & $\begin{array}{l}\text { Nursing core competency standard education; professional } \\
\text { knowledge; professional skills; medical humanistic knowledge; } \\
\text { rich clinical knowledge of interdisciplinary. }\end{array}$ \\
\hline $\begin{array}{l}\text { Hagbagher } \\
\text { y, et } \\
\text { al(2004) })^{(6)}\end{array}$ & $\begin{array}{l}\text { Iranian Nurses' } \\
\text { Understanding and } \\
\text { Experiences of } \\
\text { Professional Power }\end{array}$ & $\begin{array}{l}\text { Grounded- } \\
\text { theory } \\
\text { approach }\end{array}$ & 44 participants & $\begin{array}{l}\text { Semi-structured } \\
\text { interviews and } \\
\text { participant } \\
\text { observation } \\
\text { methods }\end{array}$ & $\begin{array}{l}\text { Application of knowledge and } \\
\text { skills gives feeling powerful in } \\
\text { nurses }\end{array}$ & $\begin{array}{l}\text { Nurses' power depends on } \\
\text { gaining and applying } \\
\text { professional knowledge and } \\
\text { skills }\end{array}$ & $\begin{array}{l}\text { Application of knowledge and skills } \\
\text { Authority; Being self-confident; Unification and solidarity; } \\
\text { Being supported, Organizational culture, and organizational } \\
\text { structure. }\end{array}$ \\
\hline $\begin{array}{l}\text { Ličen, et al } \\
(2015)^{(7)}\end{array}$ & $\begin{array}{c}\text { Nursing } \\
\text { Competency } \\
\text { Assessment Tools } \\
\text { and Possibility Use } \\
\text { in Nursing } \\
\text { Education }\end{array}$ & $\begin{array}{l}\text { Systematic } \\
\text { literature } \\
\text { review }\end{array}$ & 7 studies & $\begin{array}{l}\text { PRISMA } \\
\text { flowchart } \\
\text { methodology }\end{array}$ & $\begin{array}{l}\text { Assessment of clinical } \\
\text { competences by access to some } \\
\text { highly reliable tools }\end{array}$ & $\begin{array}{l}\text { For measures actual clinical } \\
\text { nursing competences, it is } \\
\text { important to compose an } \\
\text { assessment tool in each } \\
\text { country. }\end{array}$ & $\begin{array}{l}\text { Cognitive performance; critical thinking; general clinical skills; } \\
\text { basic biomedical science; humanity; responsibility; } \\
\text { communication; teamwork ability; patient care; ethics; } \\
\text { accountability; } \\
\text { Lifelong learning; simulation, and skill verification. }\end{array}$ \\
\hline $\begin{array}{l}\text { Ääri, et al } \\
(2008)^{(8)}\end{array}$ & $\begin{array}{l}\text { Competence in } \\
\text { Intensive and } \\
\text { Critical Care } \\
\text { Nursing. }\end{array}$ & $\begin{array}{l}\text { Systematic } \\
\text { literature } \\
\text { review }\end{array}$ & 45 article & $\begin{array}{l}\text { PRISMA } \\
\text { flowchart } \\
\text { methodology }\end{array}$ & $\begin{array}{l}\text { In intensive care nursing clinical } \\
\text { competence has three and } \\
\text { professional competence four } \\
\text { constituent domains. }\end{array}$ & $\begin{array}{l}\text { Competence in intensive care } \\
\text { nursing differs from overall } \\
\text { competence in nursing. }\end{array}$ & $\begin{array}{c}\text { Knowledge base; Skill base; Attitude and value base; } \\
\text { Experience base; Ethical activity; Decision making; } \\
\text { Collaboration; Development work; Nursing intervention; } \\
\text { Clinical guidance, and } \\
\text { Principle of nursing care. }\end{array}$ \\
\hline $\begin{array}{l}\text { Forsberg, et } \\
\text { al }(2014)^{(9)}\end{array}$ & $\begin{array}{l}\text { Clinical Reasoning } \\
\text { in Nursing is a base } \\
\text { for an Innovative } \\
\text { Assessment }\end{array}$ & $\begin{array}{l}\text { Qualitative } \\
\text { descriptive }\end{array}$ & $30 \mathrm{RNs}$ & $\begin{array}{l}\text { Short interview } \\
\text { with structured } \\
\text { questions }\end{array}$ & $\begin{array}{l}\text { For making clinical decisions, } \\
\text { high specific competence and } \\
\text { experience was so important. }\end{array}$ & $\begin{array}{l}\text { For assessing the clinical } \\
\text { reasoning process and } \\
\text { clinical decision making, } \\
\text { virtual patient's model is } \\
\text { suitable but how to score and } \\
\text { grade such exams is the } \\
\text { challenge. } \\
\end{array}$ & $\begin{array}{l}\text { Hypothesis orientation; high specific competence, and high } \\
\text { specific experience. }\end{array}$ \\
\hline
\end{tabular}


Nehrir B, et al. Competency in Nursing Students

\begin{tabular}{|c|c|c|c|c|c|c|c|}
\hline $\begin{array}{l}\text { Author \& } \\
\text { Data }\end{array}$ & Running Title & $\begin{array}{l}\text { Study } \\
\text { Design }\end{array}$ & Participants (n) & $\begin{array}{l}\text { Instrument/ } \\
\text { Tool }\end{array}$ & Main Results & Conclusion & Theme \\
\hline $\begin{array}{l}\text { Wallace, et } \\
\text { al }(2014)^{(10)}\end{array}$ & $\begin{array}{l}\text { Skill Development } \\
\text { and Reflective } \\
\text { Writing Rubrics }\end{array}$ & $\begin{array}{l}\text { Two Focus } \\
\text { groups } \\
\text { session }\end{array}$ & $\begin{array}{l}8 \mathrm{NP} \text { faculty } \\
\text { members and } \\
\text { preceptors }\end{array}$ & $\begin{array}{l}\text { Rubrics } \\
\text { (scoring tools } \\
\text { specifying } \\
\text { expectations for } \\
\text { successful } \\
\text { performance) }\end{array}$ & $\begin{array}{l}\text { Rubrics scoring tools clarify } \\
\text { levels of competency in } \\
\text { practitioner nurse }\end{array}$ & $\begin{array}{l}\text { Having a complete } \\
\text { understanding of the } \\
\text { transitional needs of new } \\
\text { NPs from students to } \\
\text { advanced practitioners can } \\
\text { markedly improve future } \\
\text { efforts in role development } \\
\text { and skill acquisition and } \\
\text { thereby ease the shortage of } \\
\text { PCPs. }\end{array}$ & $\begin{array}{l}\text { Analytic skills; Communication skills; Policy } \\
\text { development/program; Planning skills; Cultural skills; Basic } \\
\text { public; Health sciences skills; Financial planning, and } \\
\text { management skills. }\end{array}$ \\
\hline $\begin{array}{l}\text { Wilhelmsso } \\
\text { n, et al } \\
(2012)^{(11)}\end{array}$ & $\begin{array}{l}\text { Inter Professional } \\
\text { Competence }\end{array}$ & $\begin{array}{l}\text { Systematic } \\
\text { theoretical } \\
\text { base }\end{array}$ & 78 students & $\begin{array}{l}\text { The meta } \\
\text { cognitive model } \\
\text { as a tool for } \\
\text { designing IPE } \\
\text { curricula }\end{array}$ & $\begin{array}{l}\text { A meta cognitive model for inter- } \\
\text { professional education and } \\
\text { practice has been developed as a } \\
\text { tool for analyzing professional } \\
\text { competence on three levels: } \\
\text { individual, team and organization } \\
\text { with seven basic components of } \\
\text { professional competence and the } \\
\text { way they are related and interact. }\end{array}$ & $\begin{array}{l}\text { The IP learning situations for } \\
\text { IPE educators and } \\
\text { developing professional } \\
\text { practitioners is more helpful } \\
\text { than one profession's } \\
\text { perspective. }\end{array}$ & $\begin{array}{c}\text { Teamwork and group processes; Reflection and documentation; } \\
\text { Communication; Shared knowledge or general common } \\
\text { knowledge, and Ethics. }\end{array}$ \\
\hline $\begin{array}{l}\text { Kelton } \\
(2014)^{(12)}\end{array}$ & Clinical Coaching & $\begin{array}{l}\text { Systematic } \\
\text { literature } \\
\text { review }\end{array}$ & 188 students & $\begin{array}{l}\text { Clinical } \\
\text { Coaching } \\
\text { assessment }\end{array}$ & $\begin{array}{l}\text { Using Clinical Coaching model } \\
\text { for nursing students has } \\
\text { successful outcomes for them }\end{array}$ & $\begin{array}{l}\text { Clinical Coaching begins } \\
\text { with referral of a student } \\
\text { whose clinical nursing } \\
\text { practice has raised concerns } \\
\text { amongst the supervising } \\
\text { clinical staff. }\end{array}$ & $\begin{array}{l}\text { Unconsciously incompetent; Consciously incompetent; } \\
\text { consciously competent, and Unconsciously competent. }\end{array}$ \\
\hline $\begin{array}{l}\text { Hagbagher } \\
\text { y, et al } \\
(2004)^{(13)}\end{array}$ & $\begin{array}{l}\text { Effective } \\
\text { Facilitating and } \\
\text { Inhibiting Factors in } \\
\text { Clinical Decision- } \\
\text { Making }\end{array}$ & $\begin{array}{l}\text { Qualitative } \\
\text { method }\end{array}$ & 38 participants & $\begin{array}{l}\text { Semi-structured } \\
\text { interviews and } \\
\text { participant } \\
\text { observation }\end{array}$ & $\begin{array}{l}\text { Two groups of internal and } \\
\text { external variables can facilitate or } \\
\text { inhibit the nurses' clinical } \\
\text { decision making. }\end{array}$ & $\begin{array}{l}\text { Being competent and self- } \\
\text { confident are the most } \\
\text { important personal factors } \\
\text { influencing nurses clinical } \\
\text { decision-making. }\end{array}$ & $\begin{array}{l}\text { Feeling; Competent; being self-confident; Organizational } \\
\text { structure; } \\
\text { Nursing education, and being supported. }\end{array}$ \\
\hline $\begin{array}{l}\text { Olson } \\
(2014)^{(14)}\end{array}$ & $\begin{array}{l}\text { Interactive Process } \\
\text { for Cross Sectorial } \\
\text { Development }\end{array}$ & $\begin{array}{l}\text { Competenc } \\
\mathrm{y} \\
\text { discussion }\end{array}$ & 93 students & $\begin{array}{l}\text { PRISMA } \\
\text { flowchart } \\
\text { methodology }\end{array}$ & $\begin{array}{l}\text { Some domains have been used to } \\
\text { develop a framework for } \\
\text { integrating one health } \\
\text { competencies into programmers' } \\
\text { and curricula based on a common } \\
\text { understanding of an inter- } \\
\text { professional, multi-sectorial } \\
\text { approach to operating effective } \\
\text { health systems from the village to } \\
\text { the clinic. }\end{array}$ & $\begin{array}{l}\text { Priorities include the } \\
\text { production of a working set } \\
\text { of competency domains. } \\
\text { Sharing of these domains is } \\
\text { more important than } \\
\text { ownership or approval and } \\
\text { informing work in global } \\
\text { health about commonalities } \\
\text { between and among } \\
\text { development efforts forms } \\
\text { the basis for accomplishment } \\
\text { of the goal. }\end{array}$ & $\begin{array}{l}\text { Communication conflict resolution systems analysis/thinking; } \\
\text { values and ethics; Creating an enabling environment, advocating } \\
\text { change; } \\
\text { Teamwork, and leadership management. }\end{array}$ \\
\hline $\begin{array}{l}\text { Andreou, } \\
\text { et al } \\
(2013)^{(15)}\end{array}$ & $\begin{array}{l}\text { Learning Styles and } \\
\text { Critical Thinking } \\
\text { Relationship }\end{array}$ & $\begin{array}{l}\text { Systematic } \\
\text { review }\end{array}$ & 6 studies & $\begin{array}{l}\text { The guidance of } \\
\text { the Centre for } \\
\text { Reviews and } \\
\text { Dissemination }\end{array}$ & $\begin{array}{c}\text { Learning styles' diversities, weak } \\
\text { critical thinking and inconsistent } \\
\text { evolution through academic } \\
\text { progress were revealed across } \\
\text { studies. Critical thinking differed } \\
\text { significantly between learning } \\
\text { styles. }\end{array}$ & $\begin{array}{l}\text { All learning styles might be } \\
\text { positive determinants toward } \\
\text { critical thinking evolution, } \\
\text { suggesting that there is a } \\
\text { relationship between learning } \\
\text { styles and critical thinking. }\end{array}$ & $\begin{array}{l}\text { Predominant learning styles; Critical thinking scoring; Critical } \\
\text { thinking evolution across academic progress; Learning styles- } \\
\text { critical } \\
\text { thinking correlations }\end{array}$ \\
\hline
\end{tabular}


Nehrir et al. Competency in Nursing Students

\begin{tabular}{|c|c|c|c|c|c|c|c|}
\hline $\begin{array}{c}\text { Author \& } \\
\text { Data }\end{array}$ & Running Title & $\begin{array}{l}\text { Study } \\
\text { Design }\end{array}$ & Participants (n) & $\begin{array}{c}\text { Instrument/ } \\
\text { Tool }\end{array}$ & Main Results & Conclusion & Theme \\
\hline $\begin{array}{l}\text { Ballangrud, } \\
\text { et al } \\
(2014)^{(16)}\end{array}$ & $\begin{array}{l}\text { Intensive Care } \\
\text { Nurses' Perceptions } \\
\text { of Simulation-based } \\
\text { Team Training }\end{array}$ & $\begin{array}{l}\text { Qualitative } \\
\text { descriptive }\end{array}$ & $\begin{array}{l}18 \text { intensive care } \\
\text { nurses }\end{array}$ & $\begin{array}{l}\text { Individual } \\
\text { qualitative } \\
\text { interviews }\end{array}$ & $\begin{array}{l}\text { Training increases awareness of } \\
\text { clinical practice and } \\
\text { acknowledges the importance of } \\
\text { structured work in teams }\end{array}$ & $\begin{array}{l}\text { Intensive care nurses } \\
\text { perceive simulation-based } \\
\text { team training has advantages } \\
\text { for building patient safety in } \\
\text { the ICU and that realistic } \\
\text { training makes them more } \\
\text { prepared to care for severely } \\
\text { ill patients. }\end{array}$ & $\begin{array}{l}\text { Realistic training contributes to safe care reflection and } \\
\text { openness motivates learning, and finding a common } \\
\text { understanding of team performance. }\end{array}$ \\
\hline $\begin{array}{l}\text { Vanaki, et } \\
\text { al }(2009)^{(17)}\end{array}$ & Professional Ethics & $\begin{array}{l}\text { Qualitative } \\
\text { method }\end{array}$ & 36 Nurses & $\begin{array}{l}\text { Semi structured } \\
\text { interviews }\end{array}$ & $\begin{array}{c}\text { Clinical competency is acquired } \\
\text { when the nurse has an awakened } \\
\text { conscience, possesses a } \\
\text { philanthropic personality, has a } \\
\text { sense of professional } \\
\text { responsibility in any clinical } \\
\text { situation, and aims to seek out } \\
\text { essential knowledge and expertise } \\
\text { to provide care in a confident } \\
\text { manner }\end{array}$ & $\begin{array}{l}\text { Nurse resorts to sense of } \\
\text { responsibility and } \\
\text { accountability toward } \\
\text { professional } \\
\text { Obligations in the course of a } \\
\text { patient-centered approach to } \\
\text { fulfilling their diverse } \\
\text { professional duties. }\end{array}$ & $\begin{array}{l}\text { Philanthropy strong conscience; being attentive; accepting } \\
\text { responsibility; being committed to and respecting self and others } \\
\text { Appropriate; management systems; in-service training; } \\
\text { provision employment laws; control mechanisms; suitable and } \\
\text { adequate equipment; love of the profession; critical thinking; } \\
\text { nursing knowledge; professional expertise; self- assurance; self- } \\
\text { respect; responsibility; accountability; nursing science; interest } \\
\text { in profession, and professional proficiency. }\end{array}$ \\
\hline $\begin{array}{l}\text { Niezen, et } \\
\text { al }(2014)^{(18)}\end{array}$ & $\begin{array}{l}\text { Reframing } \\
\text { Professional } \\
\text { Boundaries in } \\
\text { Healthcare }\end{array}$ & $\begin{array}{l}\text { Systematic } \\
\text { literature } \\
\text { review }\end{array}$ & 13 articles & $\begin{array}{l}\text { PRISMA } \\
\text { flowchart } \\
\text { methodology }\end{array}$ & $\begin{array}{l}\text { The implementation of the NP } \\
\text { served to tackle issues such as } \\
\text { expected shortages in workforce } \\
\text { and value for money. }\end{array}$ & $\begin{array}{l}\text { Introducing nurse } \\
\text { practitioners in healthcare } \\
\text { requires organizational } \\
\text { redesign and the reframing of } \\
\text { professional boundaries. }\end{array}$ & $\begin{array}{l}\text { Knowledge and capabilities; professional boundaries; } \\
\text { organizational environment, and institutional environment. }\end{array}$ \\
\hline $\begin{array}{l}\text { Cassidy, et } \\
\text { al }(2012)^{(19)}\end{array}$ & $\begin{array}{l}\text { Preceptors' Views } \\
\text { of Assessing } \\
\text { Nursing Students }\end{array}$ & $\begin{array}{l}\text { Mixed } \\
\text { method }\end{array}$ & $\begin{array}{l}\text { Mental health and } \\
\text { intellectual } \\
\text { disability nursing } \\
\text { ( } \mathrm{n}=16) \text {. } \\
\text { Nursing } \\
\text { preceptors ( } \mathrm{n} \\
=837)\end{array}$ & $\begin{array}{l}\text { Semi-structured } \\
\text { interview }\end{array}$ & $\begin{array}{l}\text { Attitudes to competencies; being } \\
\text { a preceptor, and competencies in } \\
\text { practice were categorized. }\end{array}$ & $\begin{array}{l}\text { The importance of a regional } \\
\text { and national review of } \\
\text { competency assessment } \\
\text { systems to find a common } \\
\text { language for student } \\
\text { assessment as well as } \\
\text { promoting greater student } \\
\text { skill development within } \\
\text { competency frameworks is } \\
\text { recommended. }\end{array}$ & $\begin{array}{l}\text { Attitudes to competencies; being a preceptor, and competencies } \\
\text { in practice. }\end{array}$ \\
\hline $\begin{array}{l}\text { Cabaniss } \\
(2014)^{(20)}\end{array}$ & $\begin{array}{l}\text { Competencies of } \\
\text { Quality and Safety } \\
\text { Education }\end{array}$ & $\begin{array}{l}\text { Descriptive } \\
\text { Cross- } \\
\text { sectional }\end{array}$ & $\begin{array}{l}\text { Master's degree } \\
\text { female with } \\
\text { teaching } \\
\text { responsibilities in } \\
\text { both the } \\
\text { classroom and } \\
\text { clinical settings }\end{array}$ & Questionnaire & $\begin{array}{l}\text { Education related to the safety, } \\
\text { teamwork, and collaboration } \\
\text { competencies occurs more } \\
\text { frequently in the clinical setting } \\
\text { than in the classroom. }\end{array}$ & $\begin{array}{l}\text { The concepts of quality and } \\
\text { safety, although familiar to } \\
\text { faculty, are not identifiable } \\
\text { nor taught at the complexity } \\
\text { level. }\end{array}$ & Safety and teamwork collaboration \\
\hline
\end{tabular}


In the literature review, competency in general has been defined as "the ability to perform the task with desirable outcomes under the varied circumstances of the real world" [24], and as "the overlap of knowledge with the performance components of psychomotor skills and clinical problem solving within the realm of affective responses" [36]. Competency has general attributes that refers to having ability to successfully perform something [37]. Moreover, the concept in nursing practice has multi factorial natures including empirical evidence, behavioristic, generic, holistic role [38] and responsibility [39]. Competency has also been defined as the skill and ability to practice safely and effectively without the need for direct supervision, and as a level of performance demonstrating an effective application of knowledge, skill and judgment [40]. Moreover, competency reflects knowledge, understanding and judgment, a range of skills, and a range of personal attitudes and attributes [41].

Based on the extensive literature review in this study (Table 1), researchers believe that nursing students' competency is the individual experiences, dynamic process, and positive interactive social and beneficial changes in the equality of one's professional life which causes metacognitive abilities, touch reality, motivation, decision making, job involvement, professional authority, selfconfidence, knowledge and professional skills, in which are included the five factors of "nursing process," "caring," "professionalism," "communities," and "diversity." The basic factors of nursing students' competency (Figure 12) were provider of care, manager of care, and professional identity, all three of which are very important in the progress of nursing students. Basically, they are basically the infrastructure of nursing students' competency levels.

\subsection{Second Question: Domains of Nursing Students' Competency}

According to the review of the literature (Table1), competency in nursing students has 6 domains and 12 subdomains. Educational-based competency, Cultural-based competency, individualized-based competency, researchbased competency, professional and inter-professionalbased competency, and clinical and practical-based competency were defined as nursing students' competency domains (Figure 12).

\subsection{Third Question: Levels of Nursing Students' Competency}

The literature review (Table 1) indicated that experiences of researchers in the nursing students' competency scope [18], the three basic factors of nursing student's competency (provider of care, manager of care, and professional identity), and the combination of the matters define seven levels as follows:

1. Nursing students do not have sufficient acceptable levels of educational and clinical abilities.

2. Nursing students have sufficient and acceptable levels of educational abilities but his/her abiliities still need to be checked and supervised; they do nothave sufficient and acceptable levels of clinical abilities.

3. Nursing students have competency in educational abilities, but still need occasional checking and supervision in his/her abilities; they do not have sufficient and acceptable levels of clinical abilities, but do have minimal abilities in the clinical settings.

4. Nursing students are proficient in educational abilities, but still need periodic checking and supervision of his/her abilities; they are competent and have sufficient and acceptable levels of clinical abilities, but may also need occasional checking and supervision in his/her abilities.

5. Nursing students are expert in educational abilities, are proficient, and have sufficient and acceptable levels of clinical abilities; they may need periodic checking and supervision in his/her abilities.

6. Nursing students are expert in educational and clinical abilities, but may need to be reminded by their supervisors of some special points in educational and clinical settings .

7. Nursing students are expert in educational and clinical abilities and are teachers and supervisors of educational and clinical skills and proficiencies.

\section{Discussion}

In this study, the researchers sought to define and describe the definition, domains, and levels of nursing students' competency in light of previous studies using the systematic review approach. Definitions of competence vary by profession and country [42, 43], and many of the studies reviewed offered no clear or coherent definition or description of the mentioned concepts (Table 1). In the English language, the terms competence and competency are often used interchangeably. The term 'competency' should strictly be used for a "skill" itself, while competence is "the ability to perform that skill and the attribute of the performer" [42, 43]. In this study, nursing students' competency was clearly defined, and 6 domains with 12 subdomains of nursing student's competency were identified (Figure 2). Moreover, seven steps of nursing students' competency were introduced for the first time in competency-related literature.

The main purpose of the different domains of nursing students' competency is proper, correct, and exact use of knowledge and skills and the ability to apply the three basic factors of care management, care providing, and achieving and demonstrating a professional identity in different academic and clinical settings (Figure 12). This is congruent with the declaration that competency represents the integration of knowledge, skills, values, and attitudes [42, 43].

In other words, the definition, domains, and levels of competency should separate the novice student from the expert student in the progress of different working, academic, and clinical settings. However, there are some problematic areas in the application of the mentioned concepts, including assessment and measurement of clinical competency, general versus specific competency, and divergent values among stakeholders.

In the assessment and measurement area, it is necessary to note that competency is difficult, perhaps impossible, to measure [44]. It is also problematic to determine at what level of performance a student should be deemed competent [42, 43]. In this study, however, seven levels were identified for overcoming the problems in different clinical and academic settings. Moreover, the holistic nature of competency which "identifies broad clusters of general attributes which are considered essential for effective performance" means that competency is "more than the sum of individual competencies" [45]. This definition resists the breaking down of competency into more manageable and measurable pieces, and objective assessment of competence suffers as a result. 


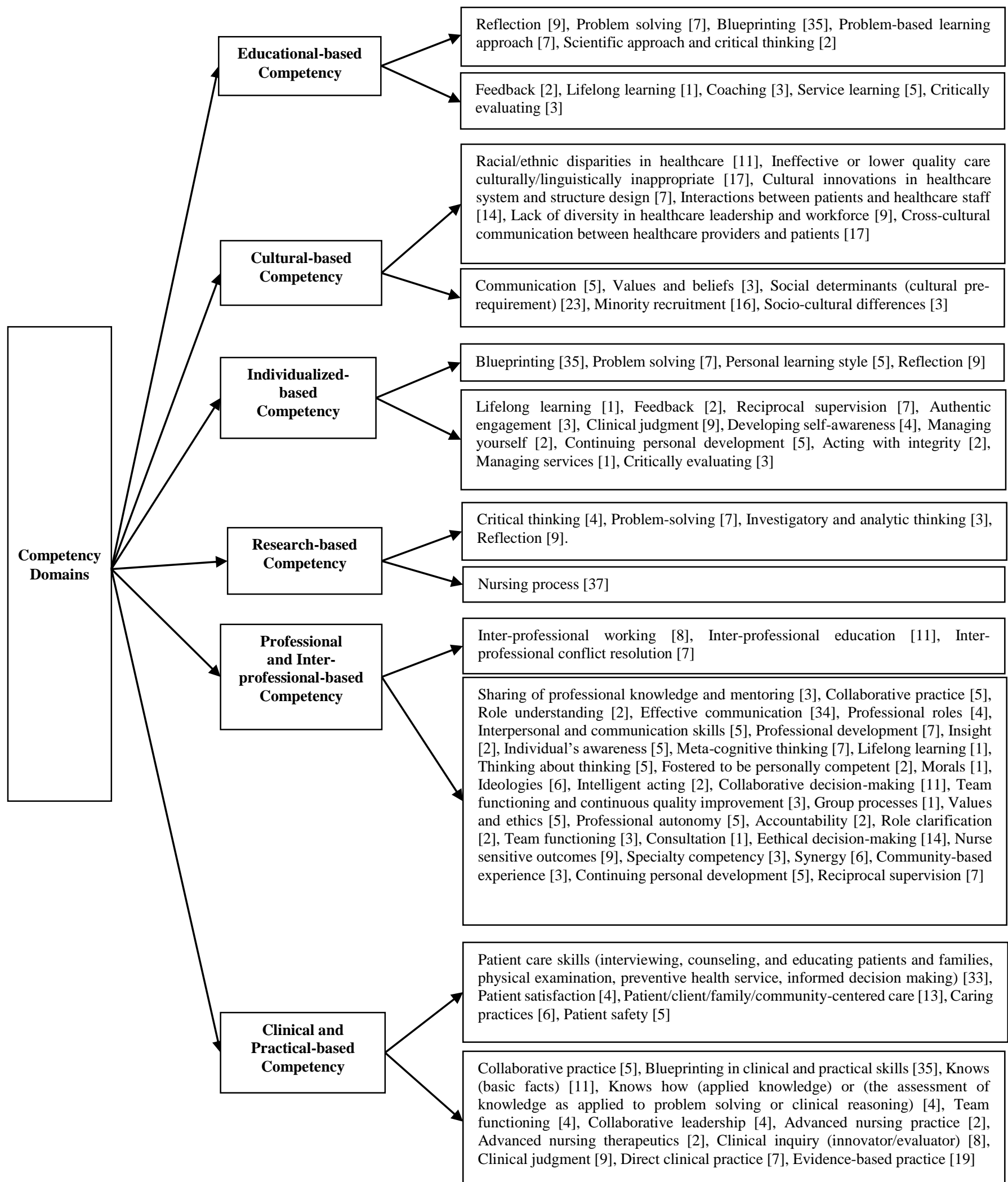

*The number in parenthesess is the frequency of repetition of an item in the whole literature review.

Figure 2. Domains of nursing students' competency

However, the study definition of nursing students' competency is congruent with the breaking down of competency into more manageable and measurable pieces and defined the concept as "the individual experiences, dynamic process, and positive interactive social and beneficial changes in the equality of one's professional life that causes meta-cognitive abilities, touch reality, motivation, decision making, job involvement, professional authority, self-confidence, knowledge and professional skills, which includes the five factors of "nursing process," "caring," "professionalism," "communities," and "diversity." Moreover, one very important point to overcoming the unclear nursing students' competency is that the determination of competency is often influenced by a student's level of comfort, confidence, and self-efficacy in a variety of contexts and considers more than one perspective 
[46]. Next, the study defined seven steps of nursing students' competency in different academic and clinical settings.

Regarding general versus specific competencies, it seems that clinical nursing skills have taken a back seat to other priorities [47-49]. The set of general competencies tends to be so vague that it fails to demarcate nursing from other professions while also failing to define nursing practices [50]; while general competencies are often used to assess students, it may be of greater benefit (and challenge) for students to attain specific nursing competencies. If students lack exposure to basic nursing skills, they may gain insufficient experience for even minimal competency [47, 49]. Furthermore, tooverpower the problem, the researcher suggested seven steps for first-year nursing students to senior nursing students.

In connection with the diverse values among stakeholders, there is often a lack of shared assumptions between educational institutions, employers, patients, and regulatory bodies about what to expect from new nursing graduates [47, 49, 51]. The researchers strongly believe that nursing stakeholders must be accompanied by the seven nursing students' competencies for different academic and clinical settings to overcome the problems.

Moreover, it is of paramount importance that the nursing students' stakeholders manage different academic and clinical settings to achieve flexibility, personalization, selfpacing, a supportive environment, a skill-based, respected, and finally affordable points in the mentioned settings [37, 52 ] in teaching different educational and practical skills and abilities in different academic and clinical settings.

\section{Conclusion}

The current study gives more comprehensively described definition, domains, and levels of nursing students' competency in different academic and clinical settings than previous studies, but it is more obvious that more systematic reviews, concept analyses, and even meta-analysis are needed to scrutinize specifically nursing students' competency in academic and clinical settings. The current study was the first review study in the nursing competency scope to introduce seven new competency levels in nursing students. However, the concept strictly depends on the profession and country.

\section{Acknowledgments}

The authors would like to thank Dr. Amir Vahedian-Azimi for his thoughtful help in methodology and critical revision of the manuscript. The information in this article was extracted from a PhD's thesis (in progress) from the Baqiyatallah University of Medical Sciences by Batool Nehrir.

\section{Authors' Contributions}

$\mathrm{BN}, \mathrm{AB}, \mathrm{ZV}, \mathrm{JMN}$, and SMKH were responsible for the study conception and design, data collection and analysis, and the drafting of the manuscript. Furthermore, they made critical revisions to the paper for important intellectual content.

\section{Financial Disclosure}

The authors declare they have no financial disclosures.

\section{Funding/Support}

This research received a full grant from the Behavioral Sciences Research Center of Baqiyatallah University of Medical Sciences and the nursing faculty of Baqiyatallah University of Medical Sciences.

\section{References}

1. Fan J-Y, Wang YH, Chao LF, Jane S-W, Hsu L-L. Performance evaluation of nursing students following competency-based education. Nurse Educ Today. 2015;35(1):97-103.

2. Francis Mwale $\mathbf{H}$. Attracting and retaining nurses to a rural hard to reach post in lesotho: A combination of financial incentives, preservice competency based curriculum and student rural clinical placements. Annals of Global Health. 2015;81(1):67.

3. Jukema JS, Harps-Timmerman A, Stoopendaal A, Smits CHM. A care improvement program acting as a powerful learning environment to support nursing students learning facilitation competencies. Nurse Educ Pract. 2015;15(6):457-62.

4. Kelton MF. Clinical Coaching-An innovative role to improve marginal nursing students' clinical practice. Nurse Educ Pract. 2014;14(6):709-13.

5. Blažun H, Kokol P, Vošner J. Research literature production on nursing competences from 1981 till 2012: A bibliometric snapshot. Nurse Educ Today. 2015;35(5):673-9.

6. Specialists NAoCN. Clinical nurse specialist core competencies: Executive summary 2006-2008. Retrieved September. 2010;14:2013.

7. Ross L, Giske T, van Leeuwen R, Baldacchino D, McSherry W, Narayanasamy A, et al. Factors contributing to student nurses'/midwives' perceived competency in spiritual care. Nurse Educ Today. 2016;36:445-51.

8. Khatiban M, Sangestani G. The effects of using problem-based learning in the clinical nursing education on the students' outcomes in Iran: A quasi-experimental study. Nurse Educ Pract. 2014;14(6):698-703.

9. Park K, Ahn Y, Kang N, Sohn M. Development of a simulation-based assessment to evaluate the clinical competencies of Korean nursing students. Nurse Educ Today. 2016;36:337-41.

10. Pereira J, Echeazarra L, Sanz-Santamaría S, Gutiérrez J. Studentgenerated online videos to develop cross-curricular and curricular competencies in Nursing Studies. Comput Human Behav. 2014;31:580-90.

11. Mikšová Z, Šamaj M, Machálková L, Ivanová K. Fulfilling the competencies of members of a nursing team. Kontakt. 2014;16(2):e108-e18.

12. Ruth-Sahd LA, Grab C. And this, too, has already changed in nursing. J Lancaster Gen Hosp. 2012;7(2):83-8.

13. Anema M, McCoy J. Competency based nursing education: guide to achieving outstanding learner outcomes: Springer Publishing Company; 2009.

14. Brown RA, Crookes PA. How do expert clinicians assess student nurses competency during workplace experience? A modified nominal group approach to devising a guidance package. Collegian.

15. Forsberg E, Ziegert K, Hult H, Fors U. Clinical reasoning in nursing, a think-aloud study using virtual patients-A base for an innovative assessment. Nurse Educ Today. 2014;34(4):538-42.

16. Higgins JP, Green S. Cochrane handbook for systematic reviews of interventions: Wiley Online Library; 2008.

17. Vahedian-Azimi A, Ebadi A, Saadat S, Ahmadi F. What is an Appropriate Nursing Care Model in Critical Care Units: Domestic or International Models. Int J Med Rev. 2014;1(2).

18. Ebadi A, Tabanejad Z, Pazokian M. Clinical Competence among MSc Students of Critical Care Nursing. Iran J Med Educ. 2015;14(12):1030-9.

19. Kim K, Han Y, Kwak Y, Kim J-s. Professional Quality of Life and Clinical Competencies among Korean Nurses. Asian Nurs Res. 2015.

20. Khomeiran RT, Yekta Z, Kiger A, Ahmadi F. Professional competence: factors described by nurses as influencing their development. Int Nurs Rev. 2006;53(1):66-72.

21. Wu F-q, Wang Y-1, Wu Y, Guo M. Application of nursing core competency standard education in the training of nursing undergraduates. Int J Nurs Sci. 2014;1(4):367-70.

22. Hagbaghery MA, Salsali M, Ahmadi F. A qualitative study of Iranian nurses' understanding and experiences of professional power. Hum Resour Health. 2004;2(1):9.

23. Ličen S, Plazar N. Identification of nursing competency assessment tools as possibility of their use in nursing education in Slovenia-A systematic literature review. Nurse Educ Today. 2015;35(4):602-8. 
24. Ääri R-L, Tarja S, Helena L-K. Competence in intensive and critical care nursing: A literature review. Intensive Crit Care Nurs. 2008;24(2):78-89.

25. Wallace D, Boller J. New nurse practitioner competencies: Skill development and reflective writing rubrics. J Nurse Pract. 2014;10(7):e13-e21.

26. Wilhelmsson M, Pelling S, Uhlin L, Owe Dahlgren L, Faresjö T, Forslund K. How to think about interprofessional competence: A metacognitive model. J Interprof Care. 2012;26(2):85-91.

27. Hagbaghery MA, Salsali M, Ahmadi F. The factors facilitating and inhibiting effective clinical decision-making in nursing: a qualitative study. BMC Nurs. 2004;3(1):2.

28. Olson DK. Competency to collaboration: an interactive process for cross-sectoral development. Lancet Glob Health. 2014;2:S39.

29. Andreou C, Papastavrou E, Merkouris A. Learning styles and critical thinking relationship in baccalaureate nursing education: a systematic review. Nurse Educ Today. 2013.

30. Ballangrud R, Hall-Lord ML, Persenius M, Hedelin B. Intensive care nurses' perceptions of simulation-based team training for building patient safety in intensive care: A descriptive qualitative study. Intensive Crit Care Nurs. 2014;30(4):179-87.

31. Vanaki Z, Memarian R. Professional ethics: beyond the clinical competency. J Prof Nurs. 2009;25(5):285-91.

32. Niezen MG, Mathijssen JJ. Reframing professional boundaries in healthcare: A systematic review of facilitators and barriers to task reallocation from the domain of medicine to the nursing domain. Health Policy. 2014;117(2):151-69.

33. Cassidy I, Butler MP, Quillinan B, Egan G, Mc Namara MC, Tuohy $\mathrm{D}$, et al. Preceptors' views of assessing nursing students using a competency based approach. Nurse Educ Pract. 2012;12(6):346-51.

34. Cabaniss R. Faculty identification of competencies addressing quality and safety education in Alabama Associate Degree Nursing Education Programs. Teach Learn Nurs. 2014;9(4):181-92.

35. McCready T. Portfolios and the assessment of competence in nursing: a literature review. Int J Nurs Stud. 2007;44(1):143-51.

36. Dunn SV, Lawson D, Robertson S, Underwood M, Clark R, Valentine $\mathrm{T}$, et al. The development of competency standards for specialist critical care nurses. J Adv Nurs. 2000;31(2):339-46.

37. ten Cate O, Scheele F. Viewpoint: competency-based postgraduate training: can we bridge the gap between theory and clinical practice?
Acad Med. 2007;82(6):542-7.

38. Evans A. Competency assessment in nursing-a summary of literature published since 2000. Autralia, EdCaN. 2008

39. Collaborative IE. Team-based competencies: building a shared foundation for education and clinical practice. Washington, DC: Interprofessional Education Collaborative. 2011.

40. Paganini MC, Egry EY. The ethical component of professional competence in nursing: an analysis. Nurs Ethics. 2011:0969733011408041.

41. Park YI, Kim JA, Ko J-K, Chung MS, Bang K-S, Choe M, et al. An identification study on core nursing competency. The Journal of Korean Academic Society of Nursing Education. 2013;19(4):663-74.

42. Pijl-Zieber EM, Barton S, Konkin J, Awosoga O, Caine V. Competence and competency-based nursing education: finding our way through the issues. Nurse Educ Today. 2014;34(5):676-8.

43. Pijl-Zieber EM, Barton S, Konkin J, Awosoga O, Caine V. Mind the gap: Quantifying the performance gap between observed and required clinical competencies in undergraduate nursing students. Nurse Educ Today. 2014;34(5):667-9.

44. Yanhua C, Watson R. A review of clinical competence assessment in nursing. Nurse Educ Today. 2011;31(8):832-6.

45. Garside JR, Nhemachena JZ. A concept analysis of competence and its transition in nursing. Nurse Educ Today. 2013;33(5):541-5.

46. Epstein RM, Hundert EM. Defining and assessing professional competence. JAMA. 2002;287(2):226-35

47. Bradshaw A, Merriman C. Nursing competence 10 years on: fit for practice and purpose yet? J Clin Nurs. 2008;17(10):1263-9.

48. Windsor C, Douglas C, Harvey T. Nursing and competencies - a natural fit: the politics of skill/competency formation in nursing. Nurs Inq. 2012;19(3):213-22.

49. Bradshaw C, O'Connor M, Butler MP, Fahy A, Tuohy D, Cassidy I, et al. Nursing students' views of clinical competence assessment. Br J Nurs. 2012;21(15):923-7.

50. Cowan DT, Norman I, Coopamah VP. Competence in nursing practice: a controversial concept-a focused review of literature. Nurse Educ Today. 2005;25(5):355-62.

51. Tilley DS. Competency in nursing: A concept analysis. J Contin Educ Nurs. 2008;39(2):58.

52. Del Bueno DJ. Competency based education. Nurse Educator. 1978;3(3):10-4. 